\title{
強風下における消波護岸からの飛沫の 発生とその低減工法 \\ SPRAY GENERATION FROM WAVE-ABSORBING SEAWALL UNDER A STRONG WIND AND ITS REDUCTION METHODS.
}

\author{
松永信博 1 ・櫨田操 2 ・香月理 3 \\ Nobuhiro MATSUNAGA Misao HASHIDA, and Osamu KATSUKI \\ 1正会員 工博 九州大学助教授 大学院総合理工学研究科 \\ （干816-0811 福岡県春日市春日公園6-1） \\ 正会員 工修 日本文理大学教授 工学部土木工学科（テ870-0316 大分県大分市一木1727） \\ 3学生員 九州大学大学院 総合理工学研究科 \\ （干816-0811 福岡県春日市春日公園6-1）
}

\begin{abstract}
Various types of wave-absorbing works have been developed to prevent coasts from wave-induced disasters and have been used with remarkable success. However, the effective dissipation of wave energy generates a large amount of sea water spray. When it is transported landward by a strong wind, severe salt damage will be caused along the coastal region. In this study, the generation of spray from a typical wave-absorbing seawall has been investigated experimentally. A parapet installed on the top of the seawall is very effective for the reduction of spray quantity. A perforated seawall method, which is proposed as a new method to reduce the spray generation, has been also examined. As a result, the new method can decrease 30-50\% of spray quantity generated by the typical seawall method.
\end{abstract}

Key Words : sea water spray, wave-absorbing seawall, spray reduction method.

1.はじめに

近年，ウォーター・フロントの開発や海上空港をはじ めとする人工島建設に伴い, 沿岸域は親水空間としてま た居住空間として利用されるようになってきた。また， わが国では台風や冬期季節風による波浪災害が沿岸域で 頻繁に発生するため, 防災対策として消波ブロック被覆 護岸工法が広く用いられてきた。しかしながら，この工 法は波浪を砕くことにより波のエネルギーを消散させる という原理のために, 強風時に多量の海水飛沫を発生さ せ，しばしば塩害を引き起こす。このような状況におい て, 消波護岸から発生する飛沫の輸送機構を明らかにす ることは沿岸域でのアメニティ向上や大気環境を保全と いう観点から重要なテーマとなっている。特に, 石田ら 1)は波と構造物の相互作用によって生ずる飛沫に注目し て, 風応力を局所的に作用させる実験を行い, 飛沫の飛 散形態を調べた。また, 松永ら 2) 3) は, 大分県別府港に 設置された消波護岸をモデルとして実験を行い，護岸背 後に輸送される飛沫量の鉛直分布および風下方向の分布 を調べた。
本研究では，広く用いられている消波護岸の模型を用 いて飛沫の発生およびその輸送過程に関する実験を行っ た。また，パラペットを護岸上に取り付けた場合の飛沫 の低減効果を調べた。さらに，消波効果を損なうことな 〈飛沫量を低減できると考えられる工法として多孔型護 岸を提案し，消波ブロック被覆護岸と比較することによ り飛沫の低減効果を検討した。

\section{2. 実験装置および実験条件}

実験は，消波ブロック被覆護岸からの飛沫の発生，パ ラペットによる飛沫の低減効果, および多孔型護岸から の飛沫の発生の 3 つに分けられる。実験には，長さ $32 \mathrm{~m}$, 高さ $0.94 \mathrm{~m}$, 幅 $0.6 \mathrm{~m}$ の矩形断面を有する風洞付き二次 元造波水槽を用いた。図-1に，実験装置の概要を示す。 水槽中央部に 2 種類の消波護岸の模型を設置し, 護岸背 後には陸域モデルとして長さ10 mにわたり水平床を設置 した。

図-2に示すように，実験対象とした消波ブロック被 


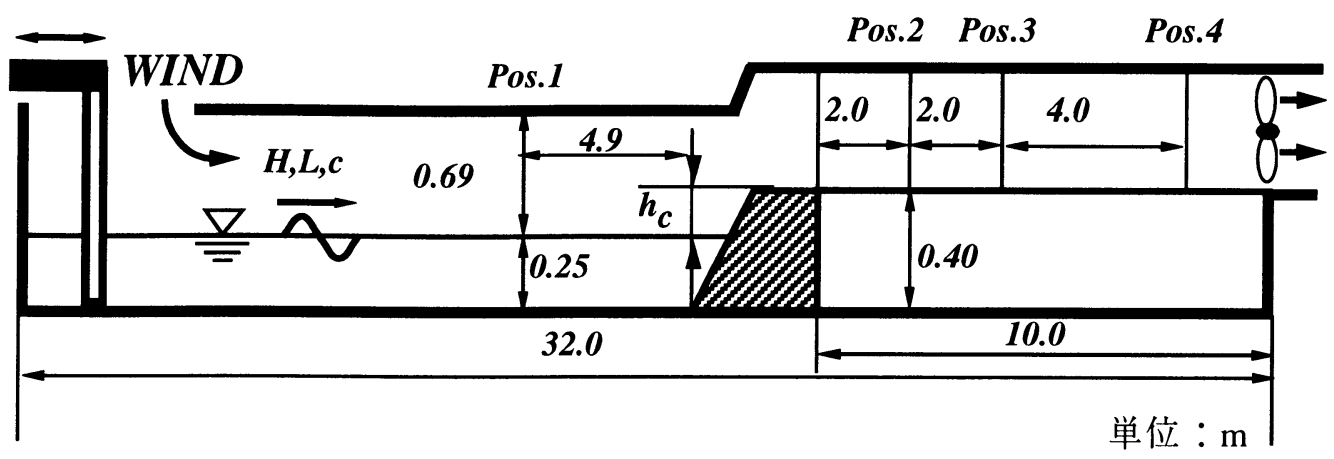

図-1 実験装置

覆護岸は3. 2 t型テトラポッドの 2 層積みで, 天端 2 個並 びである。テトラポッドの $1 / 25$ 模型を用い, 砕石砂利 （径20～40mm）の傾斜堤法面を被覆した。水平床の高さ を $40 \mathrm{~cm}$, 一様水深部の水深を $25 \mathrm{~cm}$ とた。護岸天端高さ $h_{c}$ は $15 \mathrm{~cm}$ に設定した。周期 $\mathrm{T}=1.0 \mathrm{~s}$ の二次元規則波を造 波し, 水域全体で砕波が生じる様に強風を吹かせた。砕 波しながら進行する波の波長は $156 \mathrm{~cm}$, 波高は $11.2 \mathrm{~cm}$ あった。水平床上における断面平均風速 $\mathrm{U}_{\mathrm{m}}$ を13.6, 16.1, $18.6 \mathrm{~m} / \mathrm{s}$ に変化させた。平均風速および飛沫量の測定は Pos. 1〜 Pos. 4で行った。風速はベーン式風速計を用 いて、鉛直上向きに $2 \mathrm{~cm}$ 間隔で測定した。飛沫量の測定 には、直径 $3 \mathrm{~cm}$ 、深さ $5 \mathrm{~cm}$ の円筒容器に脱脂綿を詰めた ものを用いた。その円筒容器を鉛直上向きに $4 \mathrm{~cm}$ 間隔で 取り付け、飛沫の捕集を行った。パラペットは護岸最前 部に取り付け，その高さを $2,4,6,8 \mathrm{~cm}$ と変化させ, $\mathrm{U}_{\mathrm{m}}=13.6,16.1,18.6 \mathrm{~m} / \mathrm{s}$ の風に対して飛沫量の計測を 行った。

ここで考えている多孔型護岸の形状は図-3に示すよう に，捨石上に円筒状の構造物をハニー・カム状に配列し たものである。従来の消波ブロック被覆護岸工法では, 空隙率が全断面でほほ均一（約50\%～55\%）になるよう に施工することで波を砕波し，エネルギーを吸収・消散 している。そのために飛沫が多量に発生する構造となっ ている。多孔型護岸の特徵は, 空隙率の大きい(約 $80 \%$ 以上) 円筒状の透過性構造物を斜めに設置することで砕 波の衝突による飛沫の発生量を低減し, 波のエネルギー は透過性構造物の内部，あるいは空隙率の異なる捨石な どで消散させることにある。図-4は，多孔型護岸模型を 示したものである。模型は，塩化ビニール製パイプをハ ニー・カム状に接着したもので，孔の径 Dおよびパイプ の長さ1を表-1に示すように， 3 通りずつ変えた。実験 条件は, $\mathrm{T}=1.0 \mathrm{~s}, \mathrm{U}_{\mathrm{m}}=13.6 \mathrm{~m} / \mathrm{s}$ に設定した。飛沫量を Pos. 2 と4で測定し, 消波ブロック被覆護岸からの飛沫量 と比較・検討した。いずれの護岸に対する飛沫量の実験 において，越波はほとんど認められなかった。

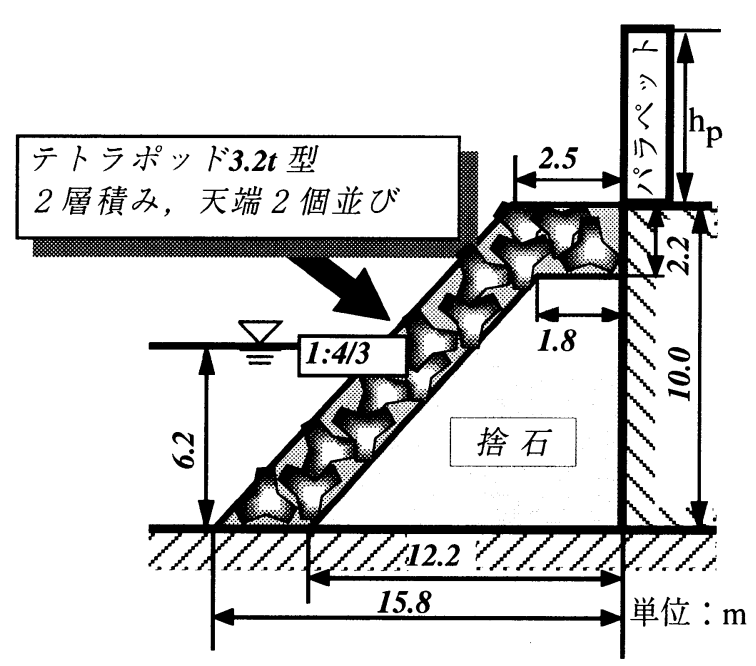

図-2＼cjkstart消波ブロック被覆護岸断面図

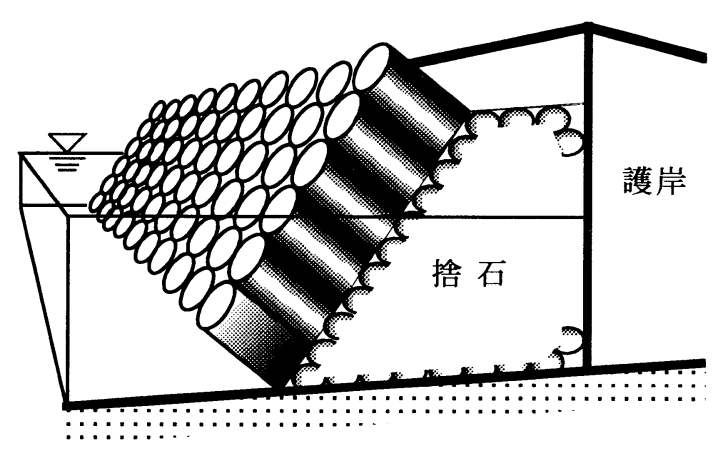

図-3 多孔型護岸のイメージ図

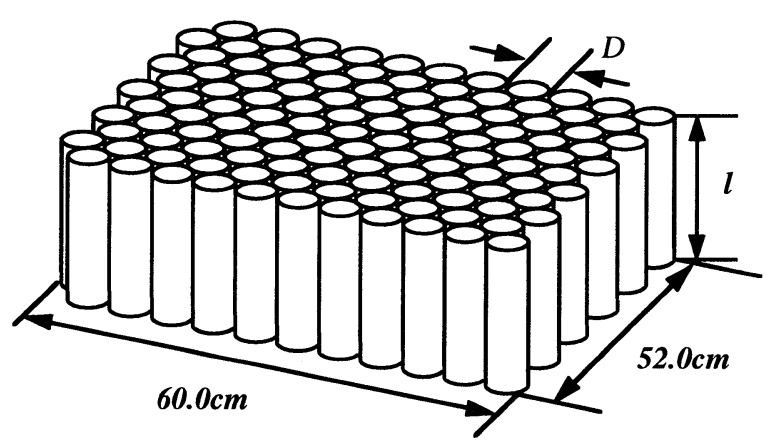

図-4 多孔型護岸模型 
表-1 多孔型護岸形状

\begin{tabular}{|c|c|c|}
\hline$R u n$ & $D(\mathrm{~mm})$ & $l(\mathrm{~mm})$ \\
\hline \hline 1 & 26 & 44 \\
\hline 2 & 26 & 88 \\
\hline 3 & 26 & 132 \\
\hline 4 & 38 & 44 \\
\hline 5 & 38 & 88 \\
\hline 6 & 38 & 132 \\
\hline 7 & 60 & 44 \\
\hline 8 & 60 & 88 \\
\hline 9 & 60 & 132 \\
\hline
\end{tabular}

\section{3. 結果と考察}

（1）消波ブロック被覆護岸における飛沫量分布

図-5(a)，（b)，(c)は，それぞれ $\mathrm{u}_{\mathrm{m}}=13.6,16.1,18.6$ $(\mathrm{m} / \mathrm{s})$ における飛沫量の鉛直分布が風下方向にどのよう に変化するかを示したものである2334)。ここで，Zは沖 合い海域 (Pos. 1) では平均水面から, 陸域(Pos. 2 4) では水平床上から鉛直上向きにとった座標である。空気 中の単位面積当たりの飛沫量 $\mathrm{g}\left(\mathrm{g} / \mathrm{cm}^{2} \mathrm{~s}\right)$ は, 測定前後の 質量差，捕集容器の断面積および捕集時間で割ることに より求められた。波が消波護岸に激しく衝突するため, Pos.2において飛沫量はかなり上方まで大きな值をとる。 風下方向に輸送されるにつれ，飛沫量は鉛直方向に指数 関数的に減少する傾向が認められる。これは，風による 飛沫の移流と重力による沈降が釣り合った移流沈降領域 が形成されていることを示す。また，図-5(a)のように 風速が小さい場合には，風下方向に飛沫量は急速に減少 する。一方，風速が大きくなると図-5(b)に示すように， 飛沫量の風下方向の低減率は小さくなる。これは, 風速 が大きい場合には，重力による飛沫の沈降よりも風によ る移流効果が卓越するためである。水平床上においては， 底面からの飛沫の供給がないため, Pos.4における飛沫 量は $\mathrm{z} \leqq 30 \mathrm{~cm}$ において水面上の飛沫量よりも少なくな る。

図-6は，飛沫量 $\mathrm{q}$ を鉛直方向に積分した值 $\mathrm{Q}(\mathrm{g} / \mathrm{cms})$ を護岸からの距離 $\mathrm{x}(\mathrm{m})$ に対してプロットしたものであ る。この図より積分值 $\mathrm{Q}$ は，風下方向に指数関数的に 減少することがわかる。また，風速が大きくなるにつれ て風下方向の低減率は小さくなり, 風による移流効果が 卓越することがわかる。

図-7は, Pos. 2 (護岸直後の測定点) の飛沫積分量 $Q_{0}$ を用いて図-6を無次元表示したものである。ここで，

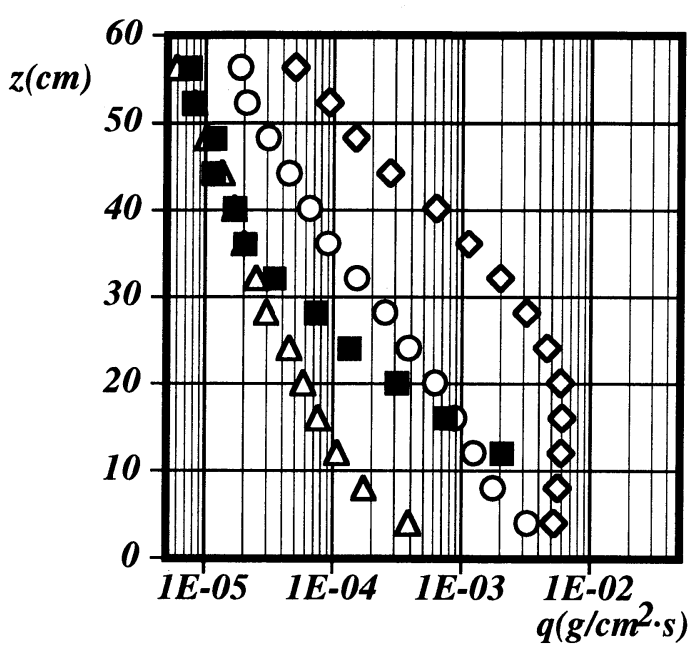

(a) $U_{m}=13.6 \mathrm{~m} / \mathrm{s}$

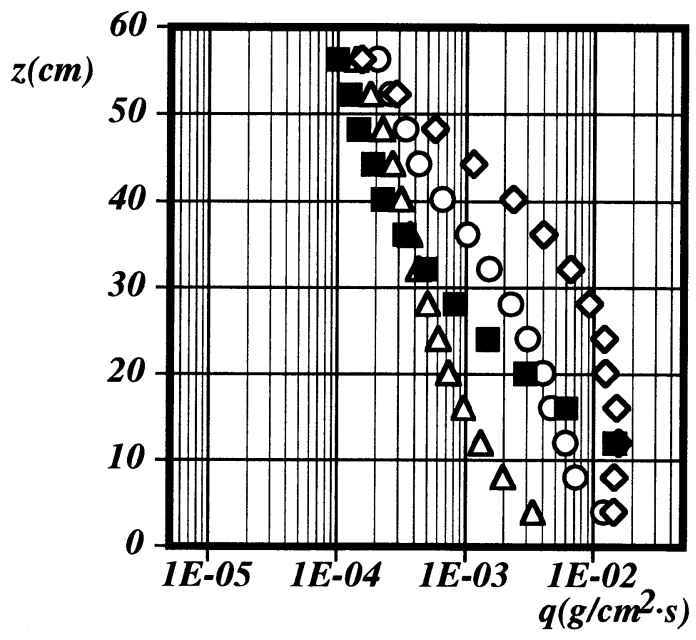

(b) $U_{m}=16.1 \mathrm{~m} / \mathrm{s}$

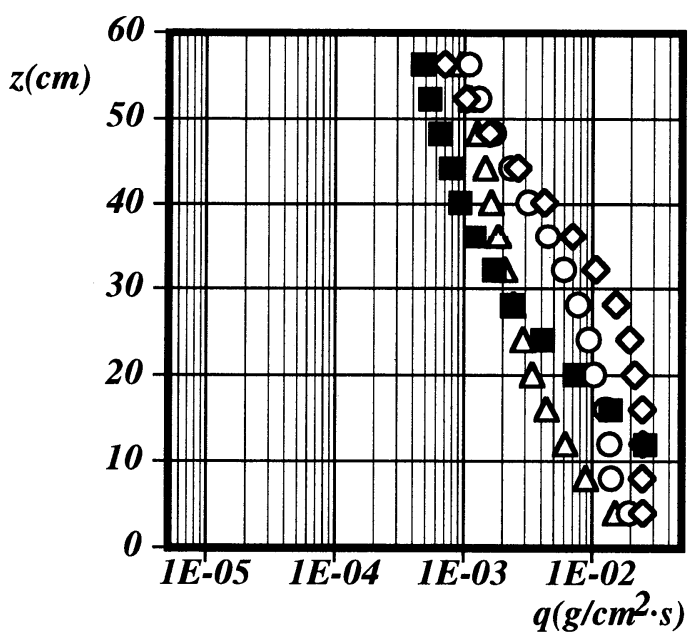

(c) $U_{\mathrm{m}}=18.6 \mathrm{~m} / \mathrm{s}$

図-5 飛沫量の鉛直分布

;Pos. 1, ৩;Pos. 2, ○;Pos. 3, $\triangle$;Pos. 4) 


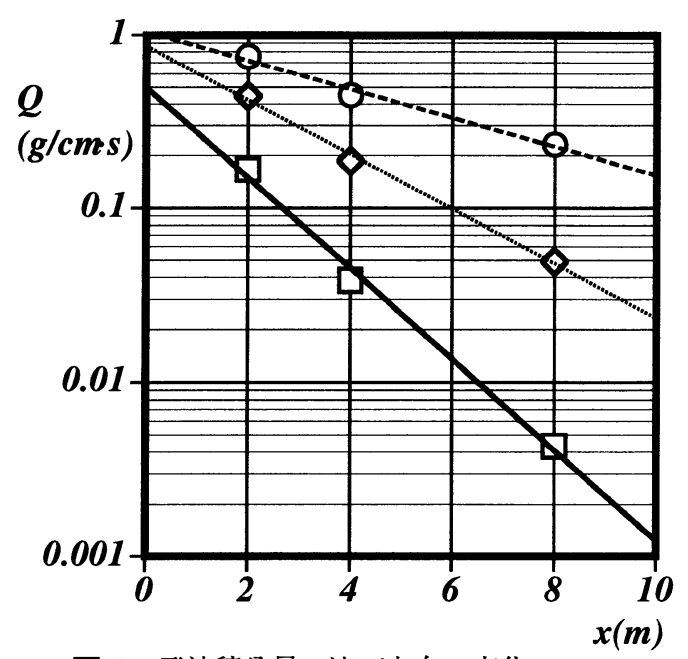

図-6 飛沫積分量の流下方向の変化

$\left(\square ; \mathrm{U}_{\mathrm{mi}}=13.6 \mathrm{~m} / \mathrm{s}, \diamond ; 16.1 \mathrm{~m} / \mathrm{s}, \bigcirc ; 18.6 \mathrm{~m} / \mathrm{s}\right)$

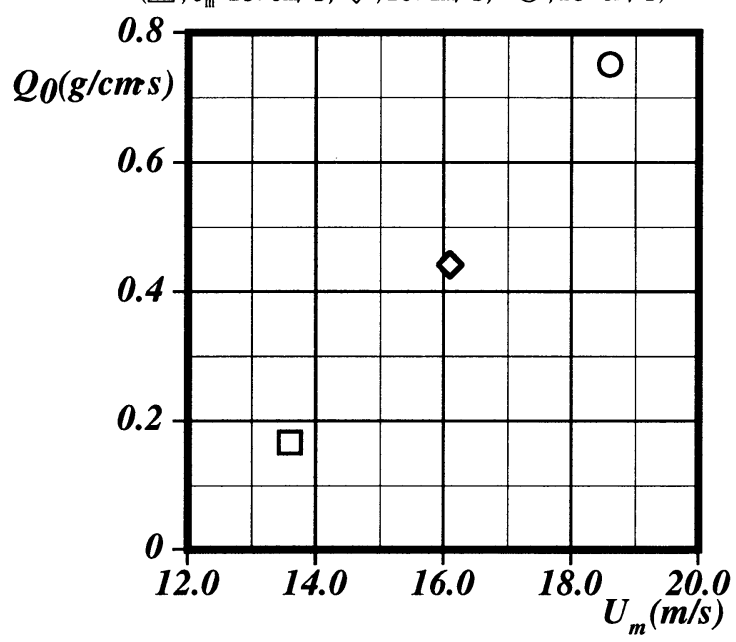

図-8＼cjkstart護岸直後の飛沫積分量と平均風速の関係

gは重力加速度である。Q $/ \mathrm{Q}_{0}$ は図中の実線とよく一致し ており, 飛沫積分量の風下方向の変化が普遍的に表され る。

図-8は, Pos. 2における飛沫積分量 $\mathrm{Q}_{0}$ と断面平均風速 $\mathrm{U}_{\mathrm{m}}$ との関倸を示したものである。今回の実験範囲では, $Q_{0}$ は風速の増加に伴い急激に増加することがわかる。図-7 と8の結果から任意の $\mathrm{x}$ に扔ける飛沫積分量を定量的に 評価することが可能となる。

（2）パラペットによる飛沫低減効果

図-9 (a)，(b)は，それぞれ消波ブロック被覆護岸に高 さが $4 \mathrm{~cm}$ と $6 \mathrm{~cm}$ のパラペットを取り付けた場合における 飛沫量 $q_{\mathrm{p}}\left(\mathrm{g} / \mathrm{cm}^{2} \mathrm{~s}\right)$ の鉛直分布を示したものである。こ の図から，護岸直後のPos.2ではパラペットが高くなる につれ，水平床近傍の飛沫量は顕著に減少することがわ

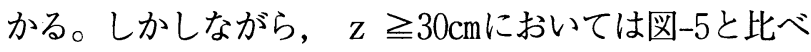
て飛沫量はむしろ増大する。これは，パラペットからの 剥離流による飛沫の供給と密接に関係があると思われる。

図-10は，飛沫量 $\mathrm{q}$ $\left(\mathrm{g} / \mathrm{cm}^{2} \mathrm{~s}\right)$ を鉛直方向に積分した 值 $Q_{p}$ x に対してプロットしたものである。護岸直後

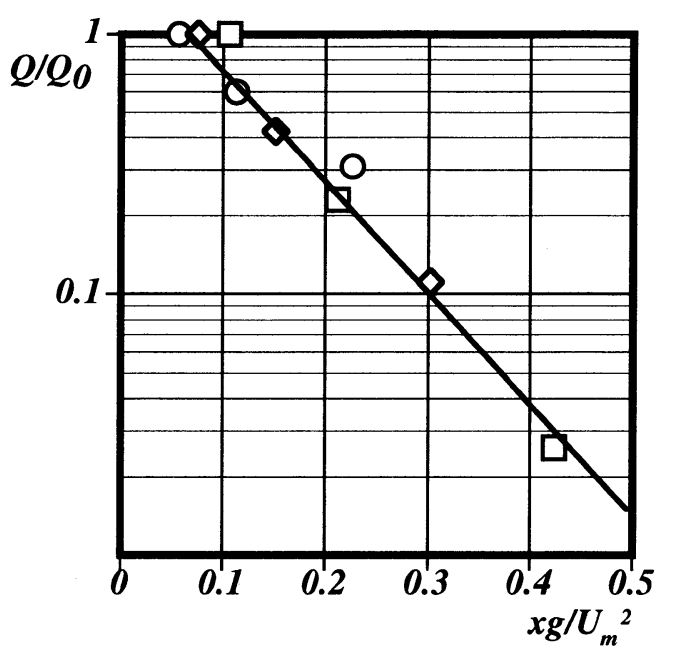

図-7 無次元飛沫積分量と無次元流下距離の関係 $\left(\square ; U_{\mathrm{m}}=13.6 \mathrm{~m} / \mathrm{s}, \diamond ; 16.1 \mathrm{~m} / \mathrm{s}, \bigcirc ; 18.6 \mathrm{~m} / \mathrm{s}\right)$
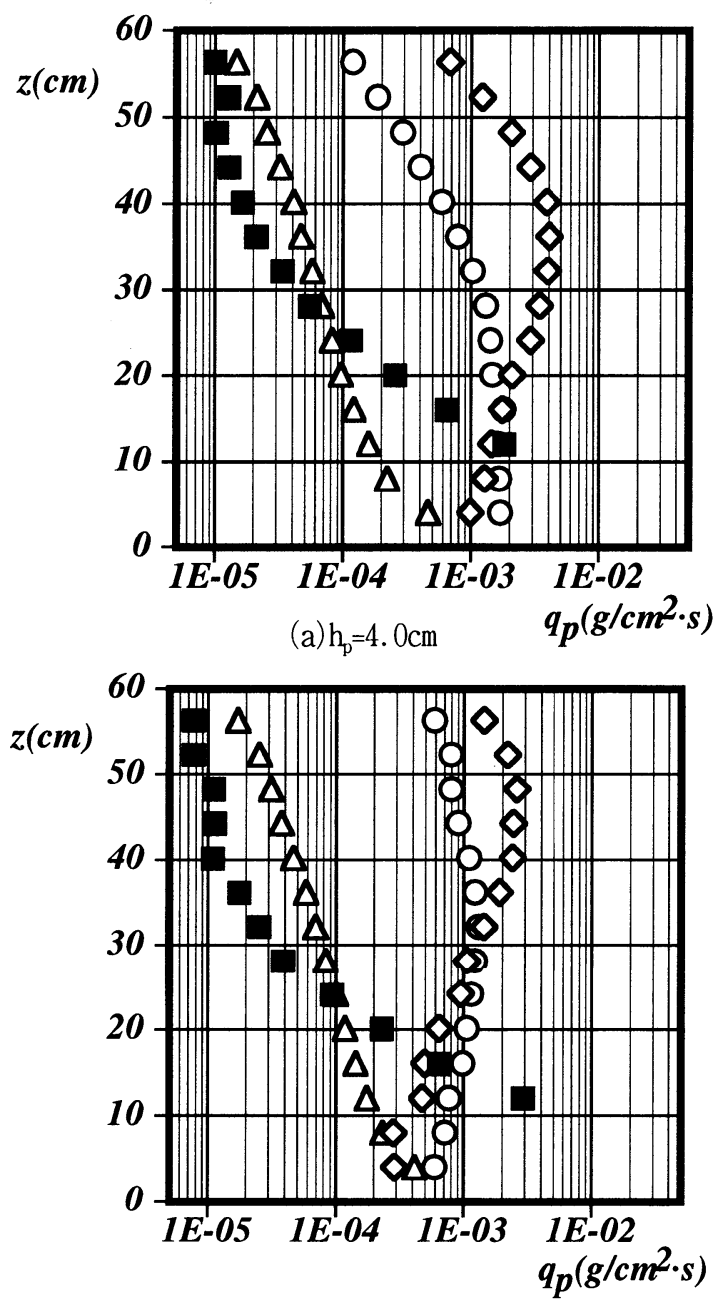

(b) $\mathrm{h}_{\mathrm{v}}=6.0 \mathrm{~cm}$

図-9 パラペット設置における飛沫量の鉛直分布

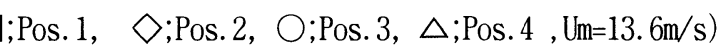

では，パラペットの高さが大きくなるにつれて飛沫積分 量は小さくなり，飛沫の低減効果は明確である。しかし ながら，風下方向に輸送されるにつれ，パラペットの高 さによる飛沫積分量の差は小さくなり, $\mathrm{x}=8 \mathrm{~m}$ ではパラ 


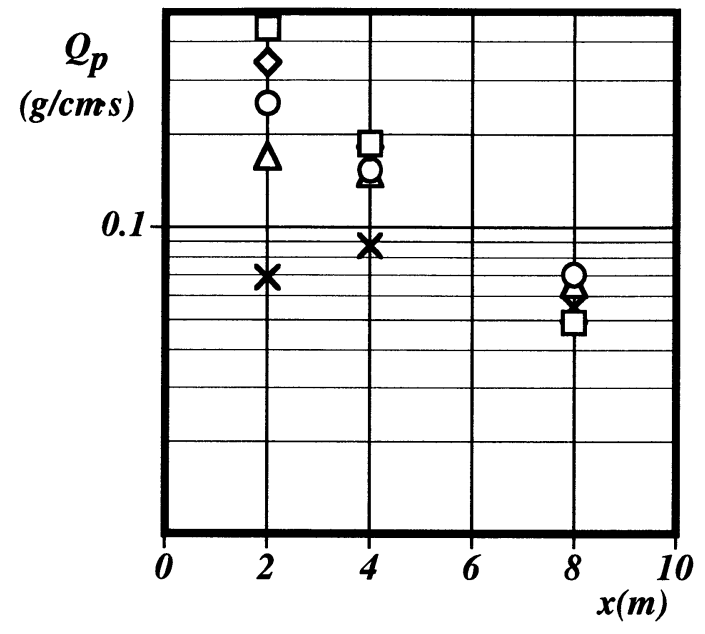

図-10 パラペット設置における飛沫積分量

$\left(\mathrm{U}_{\mathrm{m}}=16.1 \mathrm{~m} / \mathrm{s}, \square ; \mathrm{hp} / \mathrm{hc}=0, \diamond ; 1.33, \bigcirc ; 2.67\right.$, $\triangle ; 4.00, \quad \times ; 5.53)$

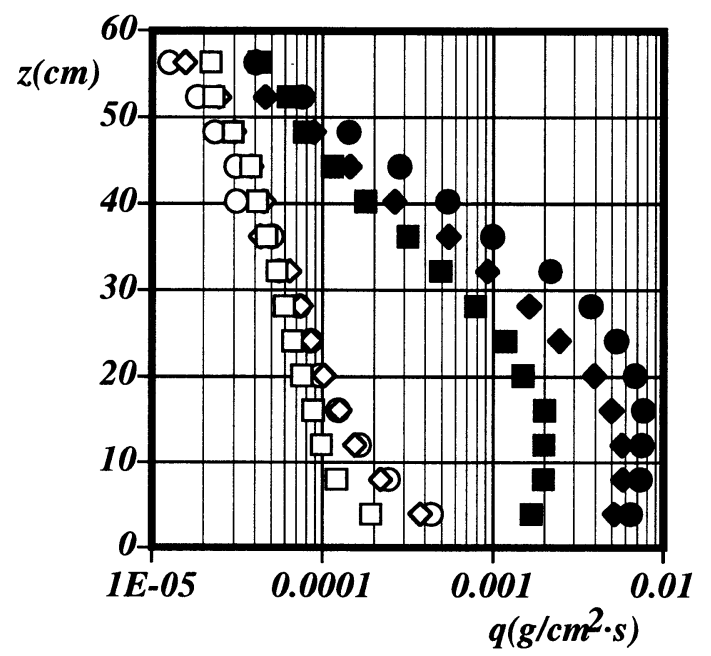

図-12 多孔型護岸からの飛沫量に及ほす Dの影響

( $\square$;Run1, $\diamond ; R u n 4, \bigcirc ; R u n 7$, 黒印はPos. 2, 白印はPos. 4 におけるデータ)

ペット高さの効果は認められなくなる。このことから， パラペットが高いほど, 護岸近傍で大きな粒径の飛沫を 遮断しているが, 護岸からの無次元距離 $\mathrm{xg} / \mathrm{U}_{\mathrm{m}}{ }^{2}=0.424$ 以上では, 沈降しにくい霧状の飛沫が存在しているため パラペットのない場合とほほ同じ值を取ると考えられる。

図-11は，Pos.2における飛沫積分量 $Q_{p 0}$ をQ $Q_{0}$ で規格化 し無次元高さ $\mathrm{hp} / \mathrm{hc}$ に対してプロットしたものである。 無次元飛沫積分量 $\mathrm{Q}_{p 0} / \mathrm{Q}_{0}$ は，ばらつきがあるもののほぼ 一つの直線に乗っており, 護岸直後の飛沫積分量は, 相対パラペット高さ $\mathrm{hp} / \mathrm{hc}$ の増加とともに線形的に減 少することがわかる。

\section{（3）多孔型護岸による飛沫低减効果}

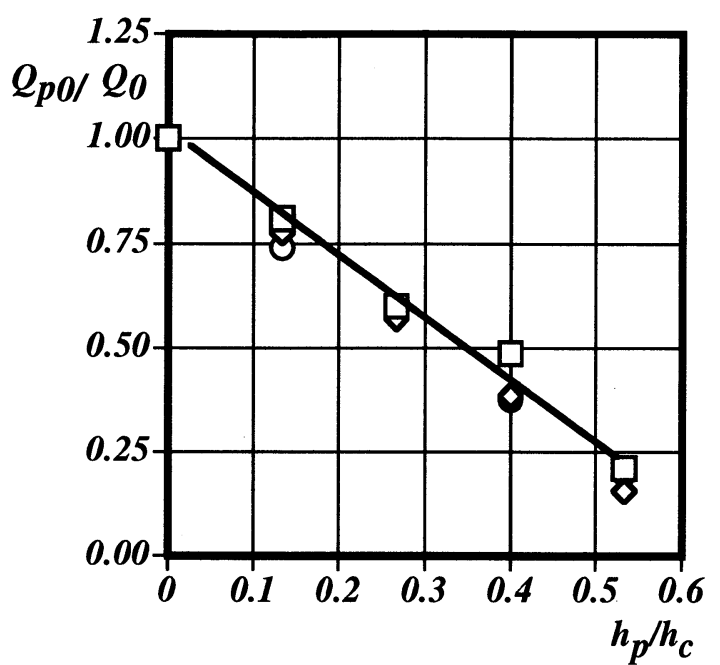

図-11 パラペット設置時における護岸背後の飛沫積分量 とパラペット高さの関係 $\left(\square ; \mathrm{U}_{\mathrm{m}}=13.6 \mathrm{~m} / \mathrm{s}\right.$, $\diamond ; 16.1 \mathrm{~m} / \mathrm{s}, \quad \bigcirc ; 18.6 \mathrm{~m} / \mathrm{s})$

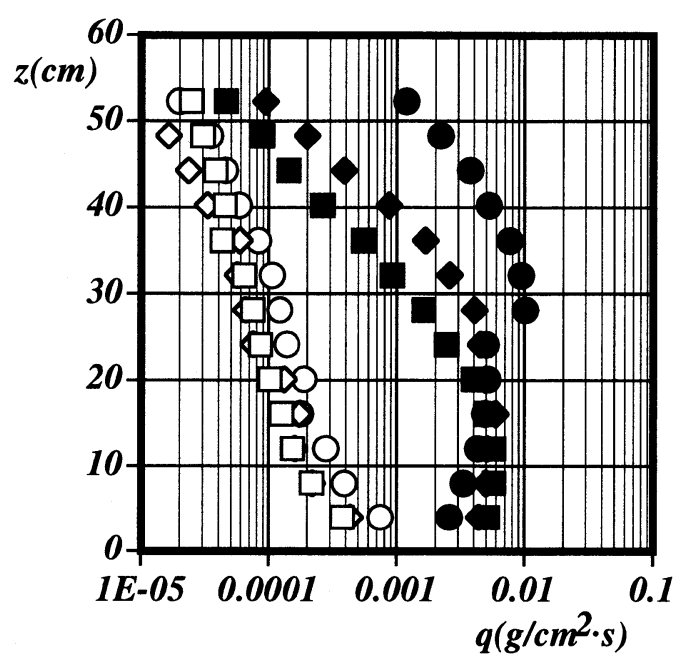

図-13多孔型護岸加らの飛沫量に及ぼす1の影響

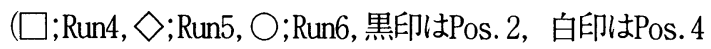
におけるデータ)

図-12は，多孔型護岸のDの違いによる飛沫の低減効果を 示したものである。この図より，Pos.2ではDが小さい ほど飛沫量は低減され，特に水平床近傍ほどその効果は 顕著である。Pos.4では, Pos.2程の差はないが, 飛沫量 の值が大きい水平床近傍で飛沫量がD減少とともに低 減していることがわかる。図-13では，多孔型護岸の1の 違いによる飛沫の低減効果を示したものである。Pos. 2 では1が短いほど飛沫量は低減され，Dによる効果の場合 とは逆に風洞水槽天井近傍においてその効果が顕著に認 められる。Pos.4では，ほとんど1による低減効果の差は 見られない。図-14(a)および(b) は, 多孔型護岸から発 生する飛沫積分量Qを示したものである。図中の直線は, 消波ブロック被覆護岸からの飛沫積分量を表す。 
$Q(\mathrm{~g} / \mathrm{cms})$

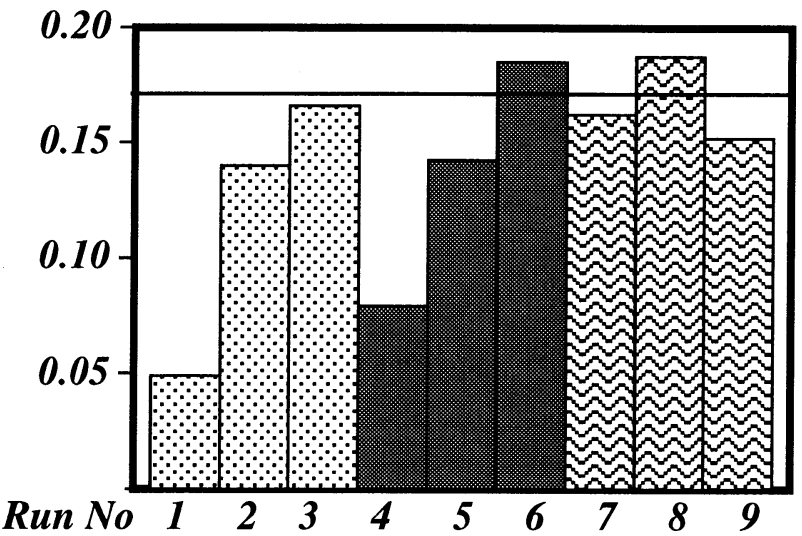

(a) Pos. 2
$Q(\mathrm{~g} / \mathrm{cms})$

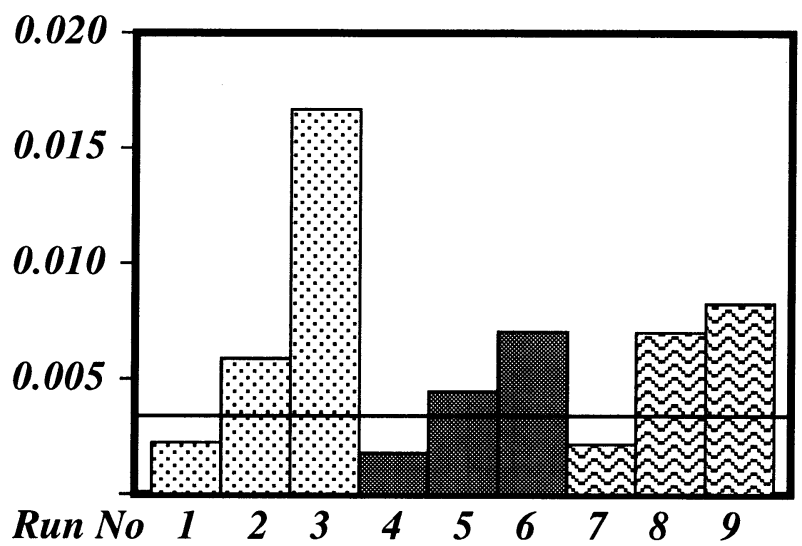

(b)Pos. 4

図-14 多孔型護岸による飛沫皘分量と消波ブロック被覆護岸によるものとの比較 (ー：消波ブロック被覆護岸からの飛沫積分量)

この図から明らかなようにPos.2においては, 多孔型護 岸から発生する飛沫量は消波ブロック被覆護岸から発生 する飛沫量よりも一般的に低いことがわかる。特に, Run1においては，消波ブロック被覆護岸からの飛沫量に 比べて Pos. 2で約70\%程度, Pos.4で約50\%低減してい る。Run № 1，4，7では，護岸背後における飛沫量は消 波ブロック被覆護岸よりも低減することがわかる。この 場合 1 は44mmであり，消波ブロックの 1 層積みの厚さに 等しいことから, 従来の消波護岸より薄い構造物で, 飛 沫量を低減できる可能性を示唆している。しかしながら， Pos.4ではRun №2，3，5，9の場合に消波ゾ山ック被覆 護岸よりも飛沫量積分值か増大している。この理由とし て, 多孔型護岸の場合には, 粒径の小さい飛沫が発生し やすいことから，飛沫はそれほど沈降せずに陸域に輸送 されると考えられる。

\section{4. 結論}

本研究では, 消波ブロック被覆護岸から発生する飛沫 量を調べ，それと比較してパラペットの設置による効果 および，飛沫発生量を低減できると考えられる多孔型護 岸からの飛沫の低減効果を調べた。それらの主な結論を 以下に示す。

1）無次元飛沫量積分值 $Q / Q_{0}$ は，異なる風速に対して 無次元距離 $\mathrm{x} \mathrm{g} / \mathrm{U}_{\mathrm{m}}^{2}$ によって普遍化することができ る。

2）パラペット設置の場合，底面付近の比較的大きな 粒径の飛沫を遮断できパラペットにより，その低減 効果が明確に認められた。

3）パラペット設置の場合, 飛沫積分量 $Q_{0}$ を用いて 規格化し，無次元パラペット高さhp/hcに対してプ
ロットすることにより普遍的に表すことができる。

4）多孔型護岸は従来工法に比べて飛沫発生量を最高 70\%程度，低減することができる。

5）低減効果の高かったパイプの長さは，従来の消波 護岸の消波ブロックの層厚さの半分と等しいことか ら, 従来の消波護岸より薄い構造物で飛沫を低減で きる可能性があることを示している。

今回の実験は限られた狭い条件のもとで行われたもの であり，沿岸域から陸域に輸送される飛沫量を定量的に 評価する為には今後さらに広範囲の条件下で実験を行う 必要がある。また，今回捉案した多孔型護岸に関しては 消波工として設計上重要である, 反射率，透過率，波力， 超波量および打ち上げ高等の評価を行うことが今後の重 要な課題である。

本研究は, 平成九, 十年度日本文理大学工学部土木工 学科櫨田研究室の卒業研究生の協力を得て行われたこと を記し，ここに謝意を表します。

\section{参考文献}

1）石田昭, 花田昌彦, 細井正延:飛沫の発生に関する実験的研 究, 第29回海岸工学講演会論文集, pp. 385-388, 1982.

2) Hashida, M. et. al. : Landward Transport of Spray Generated from a Wave Absorbing Sea Wall, Proc. 25 th Int. Conf. Coastal Eng., ASCE, 1022-1033, 1996.

3) 松永信博, 櫨田操, 入江功:消波護岸によるしぶきの発生と 護岸背後值への輸送, 海岸工学論文集, 第41巻, pp. 40464050, 1994.

4）松永信博，櫨田操，杉原裕司:巻き波砕波によって発生した 飛沫の風による輸送, 九州大学大学院総合理工学研究科報告, 第16巻, pp. 353-358, 1994

(1998. 9.30受付) 